\title{
Skuteczność inhibitorów kinazy tyrozynowej po wieloletniej terapii cytoredukcyjnej w przebiegu przewlekłej białaczki szpikowej
}

\author{
The efficacy of tyrosine kinase inhibitors after long-term \\ cytostatic therapy of chronic myelogenous leukemia
}

\author{
Małgorzata Raźny, Paweł Szwedyk \\ Oddział Hematologii i Chorób Wewnętrznych, Szpital Specjalistyczny im. Ludwika Rydygiera, Kraków
}

\begin{abstract}
Streszczenie
Przewlekta biataczka szpikowa (CML) do czasu wprowadzenia inhibitorów kinazy tyrozynowej (TKI) byta schorzeniem nowotworowym o określonym czasie przeżycia wynoszacym $w$ granicach 4-5 lat; zaledwie 3\% chorych uzyskiwato 10-letnie przeżycie. Wprowadzenie TKI pozwolito radykalnie zmienic rokowanie $w$ tym schorzeniu. W niniejszym artykule przedstawiono przypadek chorej z rozpoznaniem CML i blisko 20-letnia terapia, wyjściowo leczona hydroksymocznikiem i busulfanem, a nastepnie TKI I $i$ II generacji.
\end{abstract}

Słowa kluczowe: przewlekła białaczka szpikowa, imatynib, oporność, terapia inhibitorami kinazy tyrozynowej drugiej generacji, nietolerancja

Hematologia 2017; 8, supl. B: B1-B4

\begin{abstract}
Chronic myelogenous leukemia (CML) until tyrosine kinase inhibitors (TKI) were introduced, was a malignant disease with a definite survival time of 4-5 years, only $3 \%$ of patients achieved 10 years survival. Introduction of TKI has allowed to radically change the prognosis in this disease. In this article, a case of female patient, diagnosed with CML, with nearly 20 years of therapy, initially treated with hydroxycarbamide and busulfan followed by TKI $1^{\text {st }}$ and $2^{\text {nd }}$ generation is presented.
\end{abstract}

Key words: chronic myelogenous leukemia, resistance to imatinib, therapy with second generation tyrosine kinase inhibitors, intolerance

Hematologia 2017; 8, supl. B: B1-B4

\section{Opis przypadku}

Pacjentka w wieku 62 lat, $z$ ustalonym w 1998 roku rozpoznaniem przewlekłej białaczki szpikowej (CML, chronic myelogenous leukemia), na podstawie badania cytologicznego szpiku kostnego i badania fosfatazy alkalicznej granulocytów (FAG), trafiła do ośrodka w 2007 roku. Wyniki morfologii przy przyjęciu były następujące: liczba leukocytów (WBC, white blood count) $36 \mathrm{G} / 1$, stężenie hemoglobiny (Hb) 11,4 g/dl, liczba płytek krwi (PLT, platelets) $194 \mathrm{G} / 1$. Pacjentka w latach 1998-2007 początkowo otrzymywała busulfan, następnie hydroksykarbamid — łącznie przez 9 lat. W badaniach weryfikujących potwierdzono rozpoznanie CML $\mathrm{w}$ fazie przewlekłej $\mathrm{z}$ obecnym chromosomem

Adres do korespondencji: Małgorzata Raźny, Oddział Hematologii i Chorób Wewnętrznych, Szpital Specjalistyczny im. Ludwika Rydygiera w Krakowie, Os. Złotej Jesieni 1, 31-926 Kraków, tel. 1264684 20, faks 126468946 , e-mail: m.razny@wp.pl 
Filadelfia (Ph, Philadelphia) oraz genem fuzyjnym $B C R-A B L 1$ z transkryptem b2a2.

Pacjentkę w październiku 2007 roku zakwalifikowano do leczenia według programu terapeutycznego imatynibem w dawce $400 \mathrm{mg} /$ dobę. Po 3 miesiącach chora uzyskała odpowiedź hematologiczną. Przeprowadzona po 12 miesiącach ocena odpowiedzi cytogenetycznej wykazywała nadal obecność w 100\% komórek chromosomu Ph. Wynik wykonanego wówczas badania oporności był negatywny; nie wykazano obecności mutacji w genie $B C R-A B L 1$. Wobec niepowodzenia terapii w lutym 2009 roku wdrożono leczenie inhibitorem II generacji - dazatynibem - w dawce $100 \mathrm{mg} /$ /dobę. Pacjentka była obciążona cukrzycą leczoną lekami doustnymi. Po 12 miesiącach terapii chora uzyskała całkowitą odpowiedź cytogenetyczną, natomiast poziom transkryptu $B C R-A B L 1$, który oznaczony w 3 . miesiącu terapii osiągnął wartości SI poniżej 10\%, w kolejnych kontrolach pozostawa1 w granicach między $3 \%$ a $0,39 \%$, nie spełniając kryteriów większej remisji molekularnej (MMR, major molecular response). W trakcie terapii dazatynibem okresowo zmniejszano dawki do $75 \mathrm{mg}$ /dobę z powodu powikłań hematologicznych 3. stopnia według powszechnych kryteriów terminologicznych dla zdarzeń niepożądanych (CTCAE, Common Terminology Criteria for Adverse Events) w postaci małopłytkowości z nadirem $24 \mathrm{G} / 1$. Ze względu na długi wywiad terapii mielotoksycznej zachowywano ostrożność w dawkowaniu dazatynibu. Uzyskano odpowiedź suboptymalną według kryteriów ELN (European LeukemiaNet) z 2009 roku. Pacjentka niechętnie podchodziła do zmiany terapii zwiększającej liczbę tabletek i częstość dawkowania.

W lutym 2016 roku chora trafila na oddział, skarżąc się na duszność wysiłkową, osłabienie i spadek tolerancji wysiłku. W badaniu obrazowym klatki piersiowej potwierdzono obustronnie wysięk w obu jamach opłucnowych, przy prawidłowym badaniu echokardiograficznym. Badania morfologii pozostawały w normie: WBC 4,49 G/l, stężenie $\mathrm{Hb}$ 10,9 g/dl, liczba PLT $166 \mathrm{G} / 1$, podobnie jak badania biochemiczne. Pacjentka utrzymywała całkowitą remisję cytogenetyczną (CCR, complete cytogenetic response), w kolejnym badaniu mechanizmu oporności nie wykryto mutacji genu $B C R-A B L 1$. $Z$ powodu braku uzyskania większej odpowiedzi molekularnej i wystąpienia działań niepożądanych podjęto decyzję o zmianie terapii na kolejny inhibitor kinazy tyrozynowej (TKI, tyrosine kinase inhibitor) II generacji.

Pacjentka otrzymała nilotynib w dawce $800 \mathrm{mg} /$ dobę. Po 6 miesiącach pozostawała w CCR.
W 3. miesiącu od wdrożenia nilotynibu poziom transkryptu $B C R-A B L 1$ osiagnął wartość SI poniżej 10\%. Molekularne kontrole od września 2016 do sierpnia 2017 roku wykazały wahania poziomu transkryptu w skali IS między $0,3 \%$ a $0,2 \%$, czyli chora również nie uzyskała MMR, ale w kolejnych kontrolach przeprowadzonych w ciągu 18 miesięcy obserwowano pogłębiającą się odpowiedź molekularną (ostatni wynik na poziomie SI $0,2 \%$ ). W lipcu 2017 roku pacjentka była hospitalizowana na oddziale chorób zakaźnych i hepatologii z powodu wzrostu wskaźników wątrobowych, które odniesiono do wdrożonej ze wskazań dermatologicznych terapii hydroksychlorochiną $\left(\right.$ Plaquenil $\left.{ }^{\circledR}\right)$; po odstawieniu leku wartości transaminaz unormowały się.

\section{Dyskusja}

Wprowadzony do terapii CML w 1998 roku imatynib jako TKI I generacji pozwala na uzyskanie około $70 \%$ skutecznych odpowiedzi [1-3]. Dla większości pacjentów z CML oznacza to wydłużenie czasu przeżycia wolnego od zdarzeń (EFS, event-free survival), czasu przeżycia wolnego od progresji (PFS, progression-free survival) oraz przeżycia całkowitego (OS, overall survival). U około $30 \%$ chorych terapia imatynibem pozostaje nieskuteczna, co może wynikać między innymi $z$ oporności, nietolerancji leku lub ewolucji klonalnej choroby [4]. Biorąc pod uwagę niedostateczne odpowiedzi, należy uwzględniać również podejście chorego do terapii (compliance). Jednym $z$ bardzo istotnych czynników wpływających na skuteczność leczenia jest stopień przestrzegania zaleceń lekarskich przez pacjenta. W badaniu ADAGIO (Attenuation of Disease Progression With Azilect Given Once Daily) wykazano, że $30 \%$ chorych nie przestrzega zaleceń - dotyczy to szczególnie tych pacjentów, których oceniano jako uzyskujących suboptymalną odpowiedź. W analizie wielowariantowej według Marina i wsp. [5] potwierdzono zależność uzyskania MMR od stopnia przestrzegania zaleceń lekarskich [6].

Mechanizm oporności może wynikać $z$ przyczyn zależnych od genu $B C R-A B L$, związanych $z$ powstawaniem mutacji [7]. Oporność może się wiązać również $z$ mechanizmami niezależnymi od BCR-ABL1, związanymi z zaburzeniami wchłaniania leku w przewodzie pokarmowym, interakcjami $z$ innymi substancjami, modyfikacjami wchłaniania przez białka transportujące lek, $z$ enzymatyczną inaktywacją leku, zaburzeniami procesów apoptozy i regeneracji, pojawieniem się nowych dróg przekaźnictwa sygnałów niezależnych od genu $B C R-A B L 1$ 
[8-10]. Wprowadzenie inhibitorów II generacji pozwoliło na uzyskanie odpowiedzi w postaci CyR u przeszło połowy pacjentów opornych na leczenie imatynibem lub $z$ jego nietolerancją [11-14]. O wyborze TKI II generacji - poza swoistością występujących mutacji w obrębie kinazy BCR-ABL1 — decydują w pierwszej kolejności obecność schorzeń dodatkowych u chorego oraz ryzyko związane $z$ profilem działań niepożądanych danego inhibitora.

Na podstawie wieloośrodkowych badań jako istotny element $\mathrm{w}$ osiagganiu jak najlepszych odległych wyników uznano uzyskiwany stopień redukcji transkryptu $B C R-A B L 1$ w 3 . i 6 . miesiącu terapii, stosując TKI zarówno I, jak i II generacji. Redukcja transkryptu $B C R-A B L 1$ w SI poniżej $10 \%$ w 3. miesiącu terapii wiąże się $z$ najlepszymi wynikami przeżyć odległych zarówno w odniesieniu do PFS, jak i OS. Potwierdzenie tego założenia stanowity badania ENEST (Evaluating Nilotinib Efficacy and Safety in Clinical Trials) i DASISION (The Dasatinib Versus Imatinib Study in TreatmentNaïve Chronic Myeloid Leukemia Patients Trial), w których prowadzono ocenę przy zastosowaniu nilotynibu i dazatynibu. $W$ badaniach potwierdzono również, że wczesne uzyskanie CCR wpływa na większe odsetki 3-letniego EFS i OS. Osiągnięcie MMR w którymkolwiek momencie terapii nie wydłużało jednak EFS ani OS u chorych, którzy osiągnęli CCR $[15,16]$.

\section{Podsumowanie}

Przedstawiony przypadek przebiegu CML u pacjentki, która w chwili zachorowania miała 43 lata, i trwającej 19 lat terapii - na którą składało się 9-letnie leczenie cytostatykami, tj. busulfanem i hydroksymocznikiem — obrazują uzyskanie odpowiedzi na zastosowane leczenie $z$ wykorzystaniem dostępnych programów lekowych. Włączenie TKI I i II generacji nie doprowadziło do uzyskania optymalnej odpowiedzi w postaci MMR (w tym bardzo głębokiej odpowiedzi molekularnej MMR4,5), ale kolejne zmiany terapii przyniosły dobrze kontrolowaną odpowiedź molekularną $z$ uniknięciem toksyczności hematologicznej i pozahematologicznej. Pożądane obniżenie ilości transkryptu $B C R$ -ABL1 dzięki zastosowaniu w 3. miesiącu TKI II generacji pozwalało przewidywać dobre odległe wyniki w osiągnięciu możliwie najlepszych EFS i OS przez chorą. Występujące wahania poziomów $B C R-A B L 1$ w kolejnych oznaczeniach przeprowadzanych co 3 miesiące (SI w granicach: 0,32; 0,$2 ; 0,5 ; 0,31 ; 0,23 ; 0,26 ; 0,23 \mathrm{w}$ przypadku terapii nilotynibem) skłaniają do rozważenia kontroli przestrzegania zaleceń przez chorą i wymagają ścisłego monitorowania molekularnego.

\section{Piśmiennictwo}

1. Druker BJ, Guilhot F, O'Brien SG, et al. IRIS Investigators. Five-year follow-up of patients receiving imatinib for chronic myeloid leukemia. N Engl J Med. 2006; 355(23): 2408-2417, doi: 10.1056/ /NEJMoa062867, indexed in Pubmed: 17151364.

2. O'Brien SG, Guilhot F, Larson RA, et al. IRIS Investigators. Imatinib compared with interferon and low-dose cytarabine for newly diagnosed chronic-phase chronic myeloid leukemia. N Engl J Med. 2003; 348(11): 994-1004, doi: 10.1056/NEJMoa022457, indexed in Pubmed: 12637609.

3. Deininger M, O'Brien SG, Guilhot F, et al. International Randomized Study of Interferon Vs STI571 (IRIS) 8-year follow up: sustained survival and low risk for progression or events in patients with newly diagnosed chronic myeloid leukemia in chronic phase (CML-CP) treated with imatinib. Blood. 2009; 114: 1126.

4. de Lavallade H, Apperley JF, Khorashad JS, et al. Imatinib for newly diagnosed patients with chronic myeloid leukemia: incidence of sustained responses in an intention-to-treat analysis. J Clin Oncol. 2008; 26(20): 3358-3363, doi: 10.1200/JCO.2007.15.8154, indexed in Pubmed: 18519952.

5. Marin D, Bazeos A, Mahon FX, et al. Adherence is the critical factor for achieving molecular responses in patients with chronic myeloid leukemia who achieve complete cytogenetic responses on imatinib. J Clin Oncol. 2010; 28(14): 2381-2388, doi: 10.1200/ /JCO.2009.26.3087, indexed in Pubmed: 20385986.

6. Noens L, van Lierde MA, De Bock R, et al. Prevalence, determinants, and outcomes of nonadherence to imatinib therapy in patients with chronic myeloid leukemia: the ADAGIO study. Blood. 2009; 113(22): 5401-5411, doi: 10.1182/blood-2008-12-196543, indexed in Pubmed: 19349618.

7. Bixby D, Talpaz M. Mechanisms of resistance to tyrosine kinase inhibitors in chronic myeloid leukemia and recent therapeutic strategies to overcome resistance. Hematology Am Soc Hematol Educ Program. 2009: 461-476, doi: 10.1182/asheducation-2009.1.461, indexed in Pubmed: 20008232.

8. Apperley JF, Apperley JF. Part I: mechanisms of resistance to imatinib in chronic myeloid leukaemia. Lancet Oncol. 2007; 8(11): 1018-1029, doi: 10.1016/S1470-2045(07)70342-X, indexed in Pubmed: 17976612.

9. Thomas J, Wang L, Clark RE, et al. Active transport of imatinib into and out of cells: implications for drug resistance. Blood. 2004; 104(12): 3739-3745, doi: 10.1182/blood-2003-12-4276, indexed in Pubmed: 15315971.

10. Jordanides NE, Jorgensen HG, Holyoake TL, et al. Functional ABCG2 is overexpressed on primary CML CD34+ cells and is inhibited by imatinib mesylate. Blood. 2006; 108(4): 1370-1373, doi: 10.1182/blood-2006-02-003145, indexed in Pubmed: 16627755 .

11. Hochhaus A, Baccarani M, Deininger M, et al. Dasatinib induces durable cytogenetic responses in patients with chronic myelogenous leukemia in chronic phase with resistance or intolerance to imatinib. Leukemia. 2008; 22(6): 1200-1206, doi: 10.1038/ /leu.2008.84, indexed in Pubmed: 18401416. 
12. Kantarjian H, Pasquini R, Hamerschlak N, et al. Dasatinib or high-dose imatinib for chronic-phase chronic myeloid leukemia after failure of first-line imatinib: a randomized phase 2 trial. Blood. 2007; 109(12): 5143-5150, doi: 10.1182/blood-2006-11-056028, indexed in Pubmed: 17317857.

13. Kantarjian H, Pasquini R, Lévy V, et al. Dasatinib or high-dose imatinib for chronic-phase chronic myeloid leukemia resistant to imatinib at a dose of 400 to 600 milligrams daily: two-year follow-up of a randomized phase 2 study (START-R). Cancer. 2009; 115(18): 4136-4147, doi: 10.1002/cncr.24504, indexed in Pubmed: 19536906.

14. le Coutre PD, Giles FJ, Hochhaus A. Nilotinib in patients with $\mathrm{Ph}+$ chronic myeloid leukemia in accelerated phase following imatinib resistance or intolerance: 24-month follow-up results.
Leukemia. 2012; 26(6): 1189-1194, doi: 10.1038/leu.2011.323, indexed in Pubmed: 22076466.

15. Jabbour E, Kantarjian HM, Saglio G, et al. Early response with dasatinib or imatinib in chronic myeloid leukemia: 3-year follow-up from a randomized phase 3 trial (DASISION). Blood. 2014; 123(4): 494-500, doi: 10.1182/blood-2013-06-511592, indexed in Pubmed: 24311723.

16. Jabbour E, Kantarjian H, O'Brien S, et al. The achievement of an early complete cytogenetic response is a major determinant for outcome in patients with early chronic phase chronic myeloid leukemia treated with tyrosine kinase inhibitors. Blood. 2011; 118(17): 4541-6; quiz 4759, doi: 10.1182/blood-2011-04-348110, indexed in Pubmed: 21803854.

\section{Komentarz}

Autorzy artykułu przedstawili pacjentkę, która zachorowała na przewlekłą białaczkę szpikową przed 19 laty. Przez pierwsze 9 lat była leczona hydroksykarbamidem i busulfanem; w chwili objęcia opieką hematologiczną przez ośrodek krakowski, w 2007 roku, pozostawała w fazie przewlekłej choroby, ale bez remisji hematologicznej.

Włączenie terapii TKI wiele lat po rozpoznaniu choroby może wpływać niekorzystnie na skuteczność leczenia, ze względu na możliwą ewolucję klonalną komórek nowotworowych. U opisywanej chorej obserwowano pierwotną oporność na leczenie imatynibem (brak odpowiedzi cytogenetycznej), przy braku mutacji w domenie kinazy BCR-ABL1. Leczenie TKI II generacji początkowo dazatynibem, a następnie nilotynibem - pozwoliło na uzyskanie całkowitej odpowiedzi cytogenetycznej i obniżenie poziomu transkryptu $B C R-A B L 1$ poniżej $1 \%$. Terapia dazatynibem była powikłana toksycznością hematologiczną, co może się wiązać $z$ wcześniejszą, długotrwałą terapią lekiem alkilującym - busulfanem. Nilotynib zastosowany jako trzeci $z$ kolei inhibitor okazał się nie tylko skuteczny, ale także dobrze tolerowany.

dr hab. n. med. Joanna Góra-Tybor, prof. nadzw. Klinika Hematologii, Instytut Hematologii i Transfuzjologii 